\title{
Genetic Variability Studies in Cherry Tomato (Solanum lycopersicum L. Var. Cerasiforme Mill)
}

\author{
D.M. Renuka*, A.T. Sadashiva and Mahantesh Jogi \\ Department of Vegetable Sciences, College of Horticulture, University of Horticulture Sciences, \\ Bagalkot-587-104, Karnataka, India \\ *Corresponding author
}

\author{
A B S T R A C T
}

\begin{tabular}{|l|}
\hline Ke y w or d s \\
Variability, \\
Heritability. \\
\hline Article Info \\
\hline Accepted: \\
17 September 2017 \\
Available Online: \\
10 October 2017 \\
\hline \hline
\end{tabular}

Fourteen traits of 9 cherry tomato (Solanum lycopersicum var. cerasiforme Mill) lines exhibited a wide range of genetic variability. High geno- and phenotypic coefficients of variation were obtained for average fruit weight (67.76 and $67.9 \%$, respectively) followed by number of fruits/plant (56.45 and $57.28 \%$, respectively). High estimates of heritability, genetic advance and genotypic coefficient of variation for the traits of average fruit weight and number of fruits/plant were controlled by additive gene action indicating the possibility of selection to improve these characters. Fruit yield/plant showed high heritability along with low genetic advance. It indicates that improvement of high yield through selection is difficult; rather hybridization can be effective for improving the fruit yield/plant. Among the lines, IIHR-2754 produced the highest number of fruits/plant (498.67), maximum fruits (96.67 fruits/kg and height cluster/plant 48) and IIHR-2864 produced more fruit yield per ha (33.34t) and these lines can be selected for cultivation.

\section{Introduction}

Cherry tomato (Solanum lycopersicum L. var. cerasiforme) is a cultivated variety of tomato. It has become more popular all over the world because of a good source of vitamins A and C, solids content, good taste and fruit set even at high temperature (Prema et al., 2011). Its fruits are consumed more as a fruit rather than as a vegetable. Cherry tomato often called 'salad tomato' and is the probable ancestor of the cultivated tomato. Though cherry tomato became popular as a cash crop in some Asian countries is still new in India. It is, therefore, essential to assess the quantum of genetic variability, nature of character association with respect to different characters, which would help plant breeders in planning a successful breeding programme. Genetic parameters like genotypic coefficient of variation $(\mathrm{GCV})$, phenotypic coefficient of variation $(\mathrm{PCV})$, heritability and genetic advance are useful biometrical tools for determination of genetic variability. The yield is a complex character, quantitative in nature and an integrated function of a number of component traits. Therefore, selection for yield per se may not be much rewarding unless other yield attributing traits are taken into consideration. In the agro-ecological perspective of India, information regarding variability on cherry tomato needs to be studied for a successful breeding programme to breed new varieties. Therefore, 9 cherry 
tomato lines were evaluated for genetic variability and heritability among the characters with a view to breeding new varieties.

\section{Materials and Methods}

The experiment was conducted at the research farm of Experimental plot (Block-8) Division of vegetable crops, Indian Institute of Horticultural Research (IIHR), Hessaraghatta, Bangalore-560089 (Karnataka), nine genotypes of tomato were grown in randomized block design in three replications during Kharif and rabi season in the year 2011-2012. Seeds were sown on first week of November, 2011 in portray and transplanted in the field on first week of December, 2011. Land was prepared properly and fertilized with cow-dung, urea DAP, MOP at the rate of 10 ton, 250,440 and $250 \mathrm{~kg} / \mathrm{ha}$, respectively. Entire amount of cow-dung DAP and MOP were applied during land preparation while urea was top dressed twice at 30 and 45 days after transplanting. Each treatment or varieties in each replication was represented by a plot size of $4 \mathrm{~m} \times 4 \mathrm{~m}$ with four rows and each row consisting of 10 plants, for each genotype were planted with $75 \mathrm{~cm}$ inter row spacing, whereas plant distance were kept at $40 \mathrm{~cm}$. Irrigation, weeding and other intercultural operations were done as and when necessary. Five plants were selected randomly from each plot for collecting data on growth, yield and quality attributes for statistical analysis. The analysis of variance for each of the characters was performed using MSTAT software. The genotypic and phenotypic variances were estimated as per Johnson et al., (1955). Genoand phenotypic coefficients of variation were calculated following Burton and Devane (1953). The expected genetic advance for different characters was estimated as per Johnson et al., (1955). Estimating of genetic advance as percentage of mean was calculated following Comstock and Robinson (1952).

\section{Results and Discussion}

The genotypes were found to differ significantly among themselves for all the characters (Table 1). Some accession produced very tall plants, among the lines, IIHR-2865 was the tallest in height $(140 \mathrm{~cm})$ followed by IIHR-2871 $(131.33 \mathrm{~cm})$ and minimum was in the line IIHR-2858 $(98 \mathrm{~cm})$. Accession line IIHR-2865 had the more number of secondary branches per plant, the line IIHR-2754 had highest number of clusters/plant (48/cluster) followed by IIHR2858 (38.67/cluster).

The highest number of fruits/kg and fruits/plant were recorded in IIHR-2754 (96.67, 498.67 respectively) followed by IIHR-2858 (374.33). The lowest number of fruits/plant was recorded in IIHR-2876 (251). Average fruit weight ranged from $10-17 \mathrm{~g}$. Though Accession line IIHR-2754 produced smaller individual fruit $(10 \mathrm{~g})$ but its fruit yield/plant was $(2.2 \mathrm{~kg})$ due to higher number of fruits/plant (498). The first highest fruit yield/plant $(3.03 \mathrm{~kg})$ was recorded in IIHR2866. A wide range of yield/plant and yield/ha (1.9 to $3.03 \mathrm{~kg} /$ plant and 20 to 33 $\mathrm{t} / \mathrm{ha}$, respectively) was also reported in six cherry tomato lines by Prema et al., (2011b). Fruit firmness has obtained highest in the line IIHR-2864 $\left(7.2 \mathrm{~kg} / \mathrm{cm}^{2}\right)$ and lowest in IIHR$2860\left(4.2 \mathrm{~kg} / \mathrm{cm}^{2}\right)$. The pericap-thickness was found to be more in line IIHR-2864 $(4.8 \mathrm{~cm})$ followed by IIHR-2866 (4.03) respectively while the lowest was found in the line IIHR$2754(2.20 \mathrm{~cm})$.

The extent of variability in respect to fourteen different characters among the accession lines measured in terms of range, genotypic coefficient of variation (GCV), phenotypic coefficient of variation (PCV) along with heritability, genetic advance and genetic advance (in per cent of mean) are presented (Table 2). 
Table.1 Growth, Yield and quality attributes of 9 cherry tomato genotypes

\begin{tabular}{|c|c|c|c|c|c|c|c|c|c|c|c|c|c|c|}
\hline Parents & $\begin{array}{l}\text { Plant } \\
\text { height } \\
(\mathrm{cm})\end{array}$ & $\begin{array}{l}\text { No. of } \\
\text { pri. } \\
\text { branches }\end{array}$ & $\begin{array}{l}\text { No. of } \\
\text { sec. } \\
\text { branches }\end{array}$ & $\begin{array}{l}\text { Total } \\
\text { inflore } \\
\text { sences } \\
\end{array}$ & $\begin{array}{l}\text { fruits/ } \\
\mathrm{kg}\end{array}$ & $\begin{array}{l}\text { fruits/ } \\
\text { cluster }\end{array}$ & $\begin{array}{l}\text { Av.fruit } \\
\text { wt (g) }\end{array}$ & $\begin{array}{l}\text { fruits/ } \\
\text { plant }\end{array}$ & $\begin{array}{l}\text { yield/ } \\
\text { plant }(\mathrm{kg})\end{array}$ & $\begin{array}{l}\text { yield/ } \\
\text { plot } \\
(\mathrm{kg})\end{array}$ & $\begin{array}{l}\text { yield/ } \\
\text { ha(t) }\end{array}$ & $\begin{array}{l}\text { Locule } \\
\text { No. }\end{array}$ & $\begin{array}{l}\text { fruit } \\
\text { firmness } \\
\left(\mathrm{kg} / \mathrm{cm}^{2}\right)\end{array}$ & $\begin{array}{l}\text { pericarp } \\
\text { thickness } \\
(\mathrm{cm})\end{array}$ \\
\hline IIHR-2754 & 130.67 & 3.67 & 11.00 & 48.00 & 96.67 & 10.33 & 10.36 & 498.67 & 2.20 & 34.33 & 21.46 & 2.33 & 4.40 & 2.20 \\
\hline IIHR-2858 & 98.00 & 3.00 & 9.00 & 38.67 & 71.00 & 9.67 & 14.11 & 374.33 & 2.50 & 39.67 & 24.79 & 3.00 & 5.00 & 2.43 \\
\hline IIHR-2860 & 115.67 & 3.00 & 9.33 & 35.00 & 68.33 & 9.33 & 14.66 & 326.33 & 2.20 & 44.67 & 27.92 & 2.33 & 4.20 & 3.87 \\
\hline IIHR-2863 & 109.00 & 3.00 & 8.67 & 36.00 & 80.33 & 8.67 & 12.46 & 312.67 & 2.57 & 33.33 & 20.83 & 2.67 & 4.53 & 2.43 \\
\hline IIHR-2864 & 131.00 & 3.33 & 8.00 & 38.33 & 32.33 & 7.00 & 31.05 & 269.33 & 2.87 & 53.33 & 33.34 & 2.33 & 7.20 & 4.80 \\
\hline IIHR-2865 & 140.00 & 3.67 & 12.67 & 38.33 & 72.67 & 8.33 & 13.77 & 318.33 & 2.73 & 47.67 & 29.79 & 3.67 & 5.00 & 2.23 \\
\hline IIHR-2866 & 127.67 & 3.33 & 9.67 & 38.00 & 74.67 & 8.33 & 13.41 & 316.00 & 3.03 & 48.00 & 30.00 & 2.33 & 4.57 & 4.03 \\
\hline IIHR-2871 & 131.33 & 3.67 & 9.00 & 35.33 & 56.67 & 8.00 & 17.04 & 283.00 & 2.10 & 39.67 & 24.79 & 2.00 & 5.80 & 3.00 \\
\hline IIHR-2876 & 118.00 & 3.00 & 9.33 & 34.33 & 60.00 & 7.33 & 16.13 & 251.67 & 1.93 & 37.00 & 23.13 & 2.33 & 5.80 & 2.80 \\
\hline F ratio & $* *$ & $* *$ & $* *$ & $* *$ & $* *$ & $* *$ & $* *$ & $* *$ & $* *$ & $* *$ & $* *$ & $* *$ & $* *$ & ** \\
\hline C.V. & 3.09 & 11.39 & 9.07 & 7.17 & 4.26 & 6.95 & 4.55 & 11.01 & 5.13 & 2.57 & 2.57 & 14.02 & 3.59 & 5.67 \\
\hline
\end{tabular}

Table.2 Estimates of mean, range, genotypic and phenotypic variances, genotypic and phenotypic coefficient of variations, heritability and genetic advance in cherry tomato

\begin{tabular}{|c|c|c|c|c|c|c|c|c|c|}
\hline Characters & Mean & Range & $\mathrm{GV}$ & $\mathrm{PV}$ & $\mathrm{GCV}(\%)$ & $\mathrm{PCV}(\%)$ & $\mathrm{h}^{2}(\%)$ & GA & GA Mean $(\%)$ \\
\hline Plant height $(\mathrm{cm})$ & 132.36 & $57.6-165.6$ & 437.85 & 454.59 & 15.80 & 16.10 & 96 & 42.30 & 31.96 \\
\hline No. of pri. Branches & 3.25 & $3.0-4.3$ & 0.06 & 0.20 & 7.70 & 13.75 & 31 & 1.11 & 8.90 \\
\hline No. of sec. Branches & 8.94 & $6.0-12.6$ & 1.92 & 2.58 & 15.52 & 17.98 & 74 & 2.47 & 27.61 \\
\hline Total infloresences & 41.49 & $25.0-63.3$ & 45.02 & 53.86 & 16.17 & 17.68 & 83 & 12.63 & 30.45 \\
\hline fruits/kg & 60.69 & $11-96.6$ & 223.50 & 230.20 & 24.63 & 24.99 & 97 & 30.34 & 49.99 \\
\hline fruits/cluster & 7.87 & $4.6-10.3$ & 1.28 & 1.58 & 14.39 & 15.98 & 81 & 2.10 & 26.70 \\
\hline Av.fruit wt (g) & 19.10 & $10.3-92$ & 196.51 & 197.26 & 73.36 & 73.50 & 99 & 28.82 & 150.84 \\
\hline fruits/plant & 329.69 & $117-570$ & 6354.02 & 7671.26 & 24.17 & 26.56 & 82 & 49.44 & 45.32 \\
\hline yield/plant (kg) & 2.93 & $1.9-4.2$ & 0.24 & 0.26 & 16.83 & 17.59 & 91 & 1.84 & 33.17 \\
\hline yield/plot (kg) & 56.00 & $33.3-87$ & 158.42 & 160.50 & 22.47 & 22.62 & 98 & 25.76 & 46.00 \\
\hline yield/ha (tonnes) & 35.02 & $20.8-54.3$ & 61.88 & 62.69 & 22.47 & 22.62 & 98 & 16.10 & 46.00 \\
\hline Locule No. & 2.51 & $2.0-3.6$ & 0.085 & 0.338 & 11.55 & 23.11 & 25 & 2.52 & 11.90 \\
\hline fruit firmness $\left(\mathrm{kg} / \mathrm{cm}^{2}\right)$ & 6.10 & $3.3-9.5$ & 2.226 & 2.274 & 24.43 & 24.70 & 97 & 3.04 & 49.80 \\
\hline pericarp thickness $(\mathrm{cm})$ & 3.66 & $2.2-7.4$ & 1.200 & 1.243 & 29.89 & 30.42 & 96 & 2.21 & 60.49 \\
\hline
\end{tabular}


In general, phenotypic coefficient of variation (PCV) was higher than GCV in all the traits. GCV and PCV were high for average fruit weight (73.36 and 73.50 respectively). High values of GCV and PCV were also observed for the character pericarp-thickness (29.89 and 30.42), and yield per ha (22.47 and 22.62) The present results i.e., high estimates of phenotypic and genotypic coefficients variation $(>20 \%)$ for different characters are in agreement with the results reported by Anjum et al., (2009) in tomato and Prema et al., (2011a) in cherry tomato. And lower GCV and PCV were obtained for number of primary and secondary branches $(7.70,15.52$ and $13.75,17.98 \%$ ), plant height (15.80 and $16.10 \%)$, number of fruits/clusters (14.39 and 15.98) and yield per plant (16.83 and 17.59). Average fruit weight,fruit yield/plant, plant height, pericarp thickness, number of fruits/plant, number of fruits/cluster and number of cluster/ plant exhibited high heritability estimates $(99,91,96,96,82,81$ and $83 \%$, respectively), indicating that these characteristics are less influenced by the environment.

Genetic advance (GA) in per cent of mean was very high for Average fruit weight (150.84\%), pericarp thickness (60.49\%), fruits/kg (49.99\%), fruit firmness $(49.80 \%)$, fruits/plant (45.32 \%) pericarp thickness $(57.59 \%)$ and number of fruits/cluster $(47.57 \%)$, whereas this estimate was the lowest for number of branches (8.90 $\%)$ followed by locule number $(11.90 \%)$.

Heritability, genetic advance and genotypic coefficient of variation together could provide the best image of the amount of advance to be expected from selection (Johnson et al., 1955). In case of average fruit weight, pericarp-thickness, number of fruits/plant, high values of GA per cent of mean, heritability and GCV indicated that these characteristics were controlled by additive gene action and the selection based on phenotype for these traits might be effective. Similarly high heritability coupled with moderate GA and GCV for number of fruits/cluster, total inflorescence/plant, and branches/plant indicating that selection might be effective for this trait. However, high heritability but low GA and low GCV for plant height and fruit yield/plant showed the involvement of non-additive gene action and the selection upon this character might not be promising. Characters with low heritability with low genetic advance can be improved through hybridization (Liang and Walter 1968, Anjum et al., 2009). Therefore, the traits like number of branches of cherry tomato can only be improved through hybridization since the trait produced low heritability along with low genetic advance.

\section{References}

Anjum, A., Raj, N., Nazeer, A. and Khan, S, H., 2009, Genetic variability and selection parameters for yield and quality attributes in tomato. Indian $J$. Hort. 66(1): 73-78.

Burton, G.W., and Devane, E. H., 1953, Estimating heritability in tall fescue (Festuca arundiaceae) from replicated colonial material. Agron. J. 45: 478481.

Comstock, R. E., and Robinson, H. F., 1952, Genetic parameters, their estimation and significance. Proc. 6th Intern. Grassland Cong. 1: 248-291.

Johnson, H. W., Robinson, H. E. and Comstock, R. E., 1955, Estimates of genetic and environmental variability in soybeans. Agron. J. 47: 314-318.

Liang, G.H.L., and Walter, T.L., 1968. Heritability estimates and gene effect for agronomic traits in grain sorghum. Crop Sci. 8: 77-80.

Panse, V.G., and Sukhatme, P.V., 1967, Statistical method for Agricultural 
workers. 2nd Ed. Indian Council of Agricultural Research, New Delhi. p. 381.

Prema, G., Indiresh, K.K. and Santosha, H.M., 2011a, Studies on genetic variability in cherry tomato (Solanum lycopersicum var. cerasiforme). Asian J.
Hort. 6(1): 207-209.

Prema, G., Indiresh, K.K. and Santosha, H.M., 2011b, Evaluation of cherry tomato (Solanum lycopersicum var. cerasiforme) genotypes for growth, yield and quality traits. Asian J. Hort. 6(1): 181-184.

\section{How to cite this article:}

Renuka, D.M., A.T. Sadashiva and Mahantesh Jogi. 2017. Genetic Variability Studies in Cherry Tomato (Solanum lycopersicum L. Var. Cerasiforme Mill). Int.J.Curr.Microbiol.App.Sci. 6(10): 2085-2089. doi: https://doi.org/10.20546/ijcmas.2017.610.248 